\title{
Eddies off the southeast coast of Sakhalin Island
}

\author{
Georgy V. Shevchenko*1,2 \\ Valery N. Chastikov ${ }^{1}$ \\ Alexander T. Tsoy ${ }^{1}$
}

\author{
${ }^{1}$ Sakhalin Branch of Russian Federal Research Institute of Fisheries \\ and Oceanography, Yuzhno-Sakhalinsk, Russia \\ ${ }^{2}$ Institute of Marine Geology and Geophysics, FEB RAS, \\ Yuzhno-Sakhalinsk, Russia \\ *E-mail: shevchenko_zhora@mail.ru
}

\begin{abstract}
Rus PDF
The base of ten-day maps of sea level topography (September 2002 - October 2005) was used to study the conditions of formation and dynamics of mesoscale eddies off the southeast coast of Sakhalin Island. This base was created for the Sea of Okhotsk and adjacent areas on the ground of three satellites data. The satellite data of sea surface temperature and chlorophyll-a concentration, as well as oceanographic surveys at the standard section of Cape Aniva - Cape Dokuchaev also were used. It was shown that warm anticyclonic (AC) eddies are regularly formed as a result of meandering the Soya current at the Kunashirsky and Ekaterina straits and move to the ToninoAniva Peninsula (sometimes at some distance). The typical period of their existence is AugustOctober. Cold cyclonic eddies occurred in the same region in the second half of October as a result of the East Sakhalin current autumn amplification, and usually an AC ring is formed in Terpeniya Bay. The typical lifetime of these eddies is shorter, it is about 1-1.5 months.
\end{abstract}

\section{Keywords}

eddy, temperature, salinity, chlorophyll-a, altimetry, sea level anomaly, dynamic topography

For citation: Shevchenko G.V., Chastikov V.N., Tsoy A.T. Eddies off the southeast coast of Sakhalin Island. Geosystems of Transition Zones, 2020, vol. 4, no. 1, p. 35-45. (In Russian). https://doi.org/10.30730/2541-8912.2020.4.1.035-045

Для цитирования: Шевченко Г.В., Частиков В.Н., Цой А.Т. Вихревые образования у юго-восточного побережья о. Сахалин. Геосистемы переходных зон. 2020. Т. 4, № 1. С. 35-45.

https://doi.org/10.30730/2541-8912.2020.4.1.035-045

\section{References}

1. Andreev A.G., Zhabin I.A. 2013. [Mesoscale eddies and interannual changes in the chlorophyll-a concentration in the Sea of Okhotsk]. Okeanologicheskie issledovaniia dal'nevostochnykh morei i severozapadnoi chasti Tikhogo okeana [Oceanological studies of the Far-Eastern seas and in the North-Western Pacific Ocean]: in 2 books. Vladivostok: Dalnauka Publ., 1: 92-102.

2. Bragina I.Iu. 2002. [Seasonal and interannual variability of a zooplankton by the results of studies of 19951999 yr. in the La Pérouse Strait (the Soya Strait) and the adjacent waters]. Trudy SakhNIRO= Transactions of SakhNIRO, 4: 48-69.

3. Bulatov N.V., Kurennaia L.A., Muktepavel L.S., Aleksanina M.G., Gerbek E.E. 1999. [Eddy water structure of the Southern Okhotsk Sea and its seasonal variability (results of satellite monitoring)]. Okeanologiia $=$ Oceanology, 39(1): 29-37.

4. Farneti R. Delworth T.L. 2010. The role of mesoscale eddies in the remote oceanic response to altered Southern Hemisphere winds. J. of Physical Oceanography, 40: 2348-2354. 
5. Darnitskii V.B., Bulatov N.V. 1997. [Okhotsk Sea eddies off the Kuril Islands]. In: Kompleksnye issledovaniia ekosistem Okhotskogo moria [Complex studies of the Okhotsk Sea ecosystems]. Moscow: VNIRO, 36-39.

6. Poltev Iu.N., Tskhai Zh.R. 2019. [About a new case of capture of the large Coryphaena hippurus Linnaeus, 1758 (Perciformes: Coryphaenidae) in the waters of the south-western Sakhalin]. Trudy SakhNIRO= Transactions of SakhNIRO, 15: 303-307.

7. Samko E.V., Bulatov N.V., Kapshiter A.V. 2010. [Structure and dynamics of eddy formations in the Southern Okhotsk Sea by the satellite data]. Issledovanie Zemli iz kosmosa= Earth Observation and Remote Sensing, 4: 50-60.

8. Samko E.V., Bulatov N.V., Kapshiter A.V. 2013. [Eddy formations in the Southern Okhotsk Sea]. In: Okeanologicheskie issledovaniia dal'nevostochnykh morei i severo-zapadnoi chasti Tikhogo okeana [Oceanological studies of the Far-Eastern seas and in the North-Western Pacific Ocean]: in 2 books. Vladivostok: Dalnauka, 1: 456-464.

9. Shevchenko G.V., Romanov A.A. 2004. [Tidal properties determination in the Okhotsk Sea by the data of satellite altimetry]. Issledovanie Zemli iz kosmosa = Earth Observation and Remote Sensing, 1: 49-62.

10. Shevchenko G.V., Romanov A.A., Tsoi A.T. 2009. [Identification of mesoscale eddy structures on the southeastern shelf of Kamchatka by the satellite data]. Issledovanie Zemli iz kosmosa $=$ Earth Observation and Remote Sensing, 5: 80-89.

11. Tskhai Zh.R., Shevchenko G.V., Gavrina L.Iu. 2006. [Seasonal variations of chlorophyll-a concentration over 2001-2004 yr. in the La Pérousa Strait by the satellite and ship measurements]. Issledovanie Zemli iz kosmosa $=$ Earth Observation and Remote Sensing, 3: 15-30.

12. Raj R.P., Johannessen J.A. Eldevik T., Nilsen J.E.O., Halo I. 2016. Quantifying mesoscale eddies in the Lofoten Basin. J. of Geophysical Research: Oceans, 121: 4503-4521. https://doi.org/10.1002/2016jc011637

13. Uchimoto K., Mitsudera H., Ebuchi N., Miyazava Y. 2007. Anticyclonic eddy caused by the Soya Warm Current in an Okhotsk OGCM. J. of Oceanography, 63(3): 379-391. https://doi.org/10.1007/s10872-0070036-3

14. Vlasova G.A., Vasil'ev A.S., Shevchenko G.V. 2008. Prostranstvenno-vremennaia izmenchivost' struktury $i$ dinamiki vod Okhotskogo moria [Spatio-temporal variability of the structure and dynamics of the Sea of Okhotsk water]. Moscow: Nauka, 356 p.

15. Zhabin I.A., Luk'ianova N.B. 2011. [Anticyclonic eddies interaction with Soya Stream in the Southern Okhotsk Sea by the data of satellite observance]. Issledovanie Zemli iz kosmosa = Earth Observation and Remote Sensing, 1: 86-90.

16. Zhmur V.V. 2011. Mezomasshtabnye vikhri okeana [Mesoscale eddies in the ocean]. Moscow: GEOS, 278 p. 